2. Нищета В. Художня література в проспекції риторики: аспект виражальних риторичних засобів. Семантика мови і тексту: матеріали ХІ Міжнародної наукової конферениії (Івано-Франковськ, 26- 28 вересня 2012 р.). Івано-Франковськ: Прикарпатський національний університет імені Василя Стефаника. 2012. С. 433-436.

3. Семків Р.А. Риторика та іронія у малій прозі Івана Франка. Наукові записки НаУКМА. Т. 19 (2001). Спецвипуск. Ч. 1. С. 24-27.

4. Сірук В.Г. Діалогічний наратив у прозі Лесі Українки. Молодий вчений. 2014. № 7(10). С. 126-128.

5. Сірук В.Г. Етюд «Примара» Лесі Українки як смисловий палімпсест. Вісник Житомирського державного університету імені Івана Франка. Філологічні науки. 2019. Вип. 2(90). С.24-33.

6. Українка Леся. 3 людської намови. Проза. Київ: Видавничий центр «Академія», 2016. 384 с.

7. Яструбецька Г. Естетичне як енергематичне у творчості Лесі Українки (на прикладі оповідання «Примара»). Волинь філологічна: текст $i$ контекст 2018. № 26: Леся Українка і персоналії епохи. C. $232-240$.

DOI https://doi.org/10.30525/978-9934-26-039-1-27

\title{
ХУДОЖНЄ ВТІЛЕННЯ ПЕРФОРМАТИВНОСТІ ТІЛЕСНОГО В ПРОСКТІ ОЛЕКСАНДРА ДОВЖЕНКА «ЗЕМЛЯ»
}

\author{
Нечиталюк I. B. \\ кандидат філологічних наук, доиент, \\ доцент кафедри украйнської літератури \\ Одеського начіонального університету імені I. І. Мечникова \\ м. Одеса, Украӥна
}

У сучасній гуманітористиці поняттю «тілесність» відводиться одна 3 ключових ролей, проте інтерес до згаданої проблематики пожвавився ще на початку XX століття. Науково-технічний прогрес призвів до зміни філософської парадигми, переоцінки понять моралі та духовності (згадаймо знамените висловлювання Ніцше: «Бог помер»), народжується наука антропологія. У цей час поняття «тілесність» досліджується у феноменологічній концепції Едмунда Гусерля, працях видатних філософів XX століття Ролана Барта, П'єра Бурд'є, Жиля Дельоза, 
Моріса Мерло-Понті, Жана-Поля Сартра, Мішеля Фуко та інших. Народжується наука антропологія.

Українська культура відповідає на імпульси доби. «Пародоксальна гострота епохи - прискорений пульс сучасності і крива побутових колізій - не може вкластися в абстрактні заяложені схеми академічно перевірених літературних форм» [6, с. 178]- написав у 1928 році український режисер Лазар Френкель. Саме в літературі антропологічний поворот стає чітко окресленим. Так, на початку століття в монолозі Мавки (головної героїні «Лісової пісні» Лесі Українки) аспекти тілесності ще були виразно протиставлені проявам духовного: «О, не журися за тіло! Ясним вогнем засвітилось воно, чистим, палючим, як добре вино, вільними іскрами вгору злетіло». «Ні! Я жива! Я буду вічно жити! Я в серці маю те, що не вмирає» [3, с. 120]. Риторично наголошено на дистанціюванні духовного і тілесного, особистісні рефлексії недужої Лесі Українки просвічують у знаменитих словах про те, що дух важливіший, вагоміший за тіло. Натомість вже у творчості Володимира Винниченка лунають, під відчутним впливом філософії Ніцше та праць Фройда, зовсім інші гасла: «Змінити жорстоку моральність на слідування запитам життя» [2, с. 64]. Тілесність, фізіологічні потреби тіла для Винниченкових героїв стали засадничими ознаками культу індивіда, який відчув свою значимість.

Колізії тілесного і духовного оприявлено і в творчості Валеріана Підмогильного, який обрав для роману «Місто» досить промовисті епіграфи [Див. 4, с. 4]. Власне, всі проблеми головного героя закорінені в його досвіді того, що неможливо віднайти гармонію в протистоянні тілесного і духовного.

3 появою та розвитком мистецтва кіно поняття тілесності отримує нове наповнення. Кінематограф за природою цього виду мистецтва запрограмований, як і театральне мистецтво, на взаємодію з тілесністю. $\mathrm{He}$ випадково дослідники перформансу, зокрема Е. Фішер-Ліхте, надають значення «здійснення чогось», перетворення чогось на тілесну практику. Йдеться передусім про обмін енергіями під час театральних вистав, коли відбувається активна (у тому числі й на тілесному рівні) взаємодія акторів і глядачів.

Тілесність у кінематографі 20-х років набуває нової виразності, все більше відходить від театральності, режисери експериментують: позбавляються експресивних перебільшено гротескних жестів, сповільнюють рух, мова кіно все більше залежить від монтажу, оптики та руху камери. Безперечно, одним із найцікавіших режисерів цієї епохи $\epsilon$ Олександр Петрович Довженко. 
Для Довженка тілесність відіграє провідну роль як у кінематографі так і в художній творчості. Варто наголосити на тому фактові, що в кіноповісті «Україна в огні» вперше розкривається проблема тілесної незахищеності жінки під час війни. Довженко чи не вперше у вітчизняному культурному просторі порушив тему насилля своїх над своїми, героїня кіноповісті не захищена не тільки від чужих, тобто ворогів, а й від своїх також. Голос Довженка був одиноким на довгі десятиріччя. Наступним підняв проблему незахищеності жінки під час воєнних дій вже тільки Павло Загребельний у романі «Юлія, або запрошення до самогубства».

Та вершиною кінематографічної практики Олександра Петровича є німа драма «Земля». Фільм було знято на студії ВУФК у Києві у 1930 році. Стрічка є третім фільмом кінотрилогії («Звенигора», «Арсенал», «Земля»). Режисером та сценаристом виступив Олександр Довженко, оператором Данило Демуцький, художник-постановник Василь Кричевський. «Земля» існує одночасно у кількох мистецьких вимірах: як літературний текст (кіноповість «Земля»), як німе кіно «Земля» (причому, що музичний супровід $\epsilon$, по суті, вагомою і змінною складовою) як фотографії Бориса Косарева, який знімав процес створення фільму. Всі ці фактори роблять «Землю» унікальним проєктом.

Сюжет фільму-агітки простий, хоч і початок досить драматичний в сковородинській естетиці: помирає дід Семен. Далі у село повертається Василь $з$ новими ідеями щодо утворення колгоспів, розвитку та механізації. Куркулі (заможні селяни, в тому числі і батько головного героя) проти нововведень. Визначною подією $є$ прибуття у село трактора. Кульмінацією сюжетної дії стало вбивство Василя, переломний момент у свідомості селян. Похорон Василя супроводжує сцена пологів його матері, що символізує тісну єдність життя і смерті.

Підготовка до смерті і власне смерть діда Семена $є$ алюзією на життя та смерть Григорія Сковороди, йдеться про відому легенду про те, що Григорій Савович знав дату своєї смерті і готувався до неї. Напередодні смерті був у гарному настрої і сприймав смерть як закінчення мандрівки: «Ми народилися для справжнього щастя й мандруємо до нього. А життя наше - це дорога, що тече, як ріка» [5, с. 94].

Довженко використовує прийом паралельного монтажу, завдяки якому кожна сцена стає більш об'ємною, панорамною та експресивною. Саме в цих паралельних сценах бачимо просте життя маленької людини, яке між тим сповнене роботою, гармонією та спогляданням (дід Семен, Опанас оре, хліборобний цикл і т.д.). 
Цікаво, що Довженко в різних епізодах по-різному дивиться на функції тіла: або робить тілесність глибоко індивідуалізованою (смерть діда, танок Івана, голосіння Наталки), або ж нівелює фізіологічну складову, уніфікує, або ж і деперсоналізує акторів

Кульмінацією стрічки $є$ танець головного героя. Василь повертається 3 вдалого побачення 3 коханою, і сповнений радості буття, починає танцювати. Життєва енергія так і ллється 3 екрану. Для німого кінематографу емоції, a, особливо, радість прийнято було зображати за допомогою міміки та експресивних жестів. У нашому ж випадку «радіє» тіло, обличчя не в фокусі, глядач, споглядаючи рухи Василя, на фізичному (тілесному) рівні відчуває цілий спектр хвилюючих почуттів: радість від розділеного кохання, фізична насолода молодого тіла від побачення, передчуття ще більш прекрасного майбутнього; коли вібрує кожна клітина організму і встояти на місті, або ж йти спокійно не вистачає сил, натомість хочеться активно рухатися. Пейзаж тільки підкреслює і збирає в єдиному фокусі емоції героя. Час події - світанок, містичне сяйво якого тільки додає миті чарівності казці.

Окремо варто звернути увагу на ритм. Рухи Василя спочатку повільні i ніби непевні, а далі тіло бере гору i перемагає контроль, рухи прискорюються, стають ритмічними.

Одна 3 найсильніших сцен фільму, на мою думку, - голосіння Наталки в хаті: дівчина дізнається про вбивство коханого. Довженко щодо передачі горя знайшов несподіване (на перший погляд) рішення: Наталка гола, вона «кидає» своє тіло по кімнаті, б'є його. Всіма своїми діями дівчина демонструє, що це тіло, яке ще вчора відчувало пристрасть коханого, без нього їй непотрібне.

Драматизму ситуації додають не тільки і не стільки рухи та жести героїні, як їі оголена тілесність. Наталчино тіло - тіло дівчини, готової до материнства (широкі стегна, важкі груди, довга товста коса), до материнства, яке не станеться. Сцена 3 оголеною героїнею змушує дивитися на іiі тіло як на об'єкт, оскільки вона й сама своїми діями наче хоче відокремити його від себе (від душі). «Бути голим - це бути собою. Бути оголеним - це коли інші бачать вас роздягнутими й не визнають у вас особистість. Щоб постала оголена натура, голе тіло треба розглядати як об'єкт. (Видовисько голого тіла як об'єкта заохочує використовувати його як об'єкт)» [1, с. 58]. Новаторство Довженка зокрема полягає у тому, що сцена не несе в собі еротизму чи сексуальності, хоч такою іiі робить саме усвідомлення героїнею неможливості подальшого інтимного (статевого) життя.

$€$ ще один можливий і доволі прозаїчний момент розпачу дівчини: острах суспільного осуду. Биття (покарання) свого тіла Наталкою можна 
сприймати і як спробу позбавитися ймовірного безчестя. Тілесність в цій сцені набуває властивостей дискурсу, що утворює змістові коди.

Довженко - адепт романтичного світогляду та естет з великої літери, у нього тіло прекрасне незалежно від віку (згадаємо фокус камери на обличчі старого діда, яке сяє наче у святого), статі чи соціальної ролі. Також режисерські знахідки Олександра Довженка та операторська робота Данила Демуцького дозволяють фіксувати перформативність процесу створення тілесності, ії впливу на глядача. У «Землі» звичні речі набувають сакральності, духовність сприймається крізь посередництво тілесного, яке втрачає профанні змісти, набуваючи сенсу духовного.

\section{Література:}

1. Берджер Д. Як ми бачимо, Харків, 2020. - С. 58.

2. Винниченко В. Записки Кирпатого Мефістофіля // Прапор. - 1989. - № 2. - С. 20-84.

3. Леся Українка. Лісова пісня. - Харків: «Фактор», 2004. - 128 с.

4. Підмогильний В. Місто. - Харків: Фоліо, 2014. - 239 с.

5. Сковорода Г., Найкраще. Львів, 2019. - С. 329.

6. Френкель Л. Письменник і фотокіно. Антологія української кінокритики. Т. 3. -198 с.

DOI https://doi.org/10.30525/978-9934-26-039-1-28

\section{INTERMEDIAL POETICS OF KAZUO ISHIGURO'S FICTION}

Oprisnyk Ya. S.

$M A$,

Postgraduate Student at the World Literature Department

Ivan Franko National University of Lviv

Lviv, Ukraine

\section{Senchuk I. A.}

Ph. D. in Philology, Associate Professor, Associate Professor at the World Literature Department

Ivan Franko National University of Lviv

Lviv, Ukraine

The recent tendency towards the study of interdisciplinary links (medial border-crossings) and interrelationship between different forms of art has led 